\title{
GENETICAL ANALYSIS OF YIELD AND ITS COMPONENTS FOR THREE FABA BEAN CROSSES USING SIX PARAMETER MODELS
}

\author{
Gehan G. A. Abou-Zaid \\ Field Crops Research Institute, Food Legumes section, ARC , Egypt. \\ Received: Dec. 2, 2017 \\ Accepted: Dec. 30, 2017
}

\begin{abstract}
The objectives of this study were to estimates some genetic parameters of yield and its components as well as the extent of heterosis, inbreeding depression, heritability, genetic advance and behavior of gene action in three faba bean crosses. This investigation was carried out at Sakha Agricultural Research Station, ARC, Kafr El-Sheikh, Egypt during 2012 / 13, 2013 / 14 and 2014 / 15 seasons. Six populations; $P_{1}, P_{2}, F_{1}, F_{2}, B C_{1}$ and $B C_{2}$ of the three crosses i., e, Giza $40 \times D$ 2, Giza $40 \times D 5$ and Giza $40 \times D 8$ were sown in randomized complete blocks design with three replications. The data were analyzed by generation mean analysis method proposed by Gamble (1962). Scaling test was significantly differed from zero for all traits in all crosses, indicating the presence of all types of non -allelic interactions. Positive and significant dominance gene effects was observed for most of the studied traits in the three crosses, whereas, the (additive $x$ additive) gene effects were relatively more important than the additive (a) effects but less important than dominance effects. The dominance $x$ dominance $(d d)$ gene effects were more important and higher in magnitude than additive $x$ additive (aa) epistatic effects in the inheritance of most studied traits in all crosses. Significant heterosis over mid-parent in desirable direction was found for yield and its components in the three crosses due to over-dominance in most cases. It could be concluded that selection for seed yield and its components should be delayed to later generations in breeding programs.

Positive and highly significant heterosis over better - parent was obtained for number of pods and seeds / plant in the first and second crosses, seed yield / plant and 100-seed weight in the second and third crosses. Significant positive values of inbreeding depression were detected for number of branches / plant in the first and third crosses, number of seeds / plant in the first cross, number of pods / plant and seed yield / plant in the first and second crosses. Heritability estimates in broad-sense were higher than corresponding values of narrow-sense in all crosses. Heritability estimates in narrow-sense were low for plant height in the second cross (14.39\%) and seed yield / plant in the same cross (17.53\%), indicating that these traits were influenced by non-heritable effects. The high values of predicted genetic advance (Ga \%) were associated with high values of narrow-sense heritability and vise-versa.
\end{abstract}

Key words: Faba bean,. Inbreeding depression, Heritability, Gene action, Phenotypic and genotypic coefficient of variations, Heterosis .

\section{INTRODUCTION}

Faba bean is one of the oldest crops in the world. Globally, faba bean (Vicia faba L.) is the most important legume crop in Egypt, has considerable importance as a low cost food rich in protein content that ranged from $22 \%-38 \%$ (Griffiths and Lawes,1978) and carbohydrates. Due to its high nutritive value for human food and its role as a break crop in cereal rotation system. The cultivated area was about 113.810 feddan in the least five seasons with an average yield of 9.2 ardab /Fadden. The total production in 2015/16 season was about 119.000 tons, while the total consumption was estimated to be about 420.000 tons. This means that, the percentage of self-sufficiency is only about $32.6 \%$. So, to reduce the gap between production and consumption, the most effective is being developing new cultivars with high yielding potentiality and using the proper cultural practices. 
Faba bean could share the importance with wheat as a winter crop. It brings the plant breeders attention to breed faba bean suitable to grow in arid condition with high yielding ability, high total protein content and early maturity. These estimates are useful to initiate such breeding program in order to improve productivity and quality of the crop. For a breeding program to be successful there must be genetic differences among the individual plants of the breeder's collection of material. Then the breeder will be able to select the desirable combination of genes. Many desirable traits such as yield, protein content and quality are under the control of many genes and the environmental factors. The environment affects the expression of the character and there will be no discrete classes of phenotype and there are continuous variations of this character. Such quantitative variations need statistical techniques for their evaluation

Six parameter model analysis suggested by Gamble (1962) is considered as the most important analysis method which supply the breeder by the information about the nature of gene action. Heterosis, inbreeding depression, heritability and predicted genetic gain from selection for given characters, were important to supply the breeder to choose the suitable breeding program for improvement of his genetic material in his hand.

The aim of the present investigation is to genetically analysis of yield and its components as well as the extent of heterosis, inbreeding depression, heritability and genetic advance behavior of gene action in three faba bean crosses.

* Economic Affairs Sector, Ministry of Agriculture

\section{MATERIALS AND METHODS}

A field experiments were conducted at the Farm Sakha Agricultural Research Station (SARS), during three seasons, 2012 /2013, 2013 /2014 and 2014 /2015. In the first season, four parent genotypes of faba bean namely; Giza40, Determinant 2, Determinant 5 and Determinant 8 were sown and crossed under the isolation wire cage at SARS to produce $F_{1}$ seeds. Three crosses were produced namely; Cross I (Giza40 x D2), cross II (Giza40 x D5) and cross III (Giza40 x D8). The origin, pedigree, disease reaction and other agronomic characters of these parents are presented in Table (1). In 2013 / 2014 season, F F's and their correspondent parents were sown under wire cages, where $F_{1}$ plants were selfed and backcrossed to each parent under the same wire cages to obtain the $F_{2}$, $\mathrm{BC}_{1}$ and $\mathrm{BC}_{2}$ for each cross. The crosses were made again between the parents of each cross to obtain enough $F_{1}$ seeds. The six populations i. e; $\mathrm{P}_{1}, \mathrm{P}_{2}, \mathrm{~F}_{1}, \mathrm{~s}, \mathrm{~F}_{2}, \mathrm{BC}_{1}$ and $\mathrm{BC}_{2}$ of the three faba bean crosses were sown during the third season 2014 /2015. The experiment was arranged in a randomized complete blocks design (RCBD) with three replications. The plants were sown in ridges of three meters long and 60 $\mathrm{cm}$ wide. Hills were spaced $20 \mathrm{~cm}$ apart with one seed per hill. Plots varied in size; for segregation generation 20 rows $F_{2}$, five rows for $\mathrm{BC}_{1}$ and $\mathrm{BC}_{2}$ and three rows for nonsegregation generation $\mathrm{P}_{1}, \mathrm{P}_{2}$ and $\mathrm{F}_{1}$. Data were recorded observations on individual guarded plants of each the $P_{1}, P_{2}, F_{1}, s, F_{2}$, $B C_{1}$ and $B C_{2}$ of each crosses for the following agronomic characters: Flowering date (day), Plant height $(\mathrm{cm})$, number of branches / plant, number of pods / plant, number of seed/plant, 100- seed weight $(\mathrm{g})$ and Seed yield / plant (g).

Statistical and genetic procedures: In the present study to determine the presence or absence of non-allelic interaction, scaling test as outlined by Mather (1949) was used to test for epistasis. The six-parameter genetic model of Jinks and Jones (1958) was applied to separate out the components of genetic variance to its main effects additive and dominance and their respective first order interactions i.e., additive $\mathrm{x}$ additive, additive $\mathrm{x}$ dominance and dominance $x$ dominance, quantities. $A, B, C$ and $D$ and their variances were calculated to test the adequacy of the additive-dominance model in each case where: 
Table 1: The names, Pedigree, diseases reaction, maturity and agronomic characters of four parental faba bean varieties used in this study.

\begin{tabular}{|c|c|c|c|c|c|c|}
\hline \multirow[t]{2}{*}{ No. } & \multirow[t]{2}{*}{ Parents } & \multirow[t]{2}{*}{ Pedigree } & \multirow{2}{*}{$\begin{array}{l}\text { Disease } \\
\text { reaction }\end{array}$} & \multirow{2}{*}{ Maturity } & \multicolumn{2}{|c|}{ Agronomic traits } \\
\hline & & & & & Seed coat color & $\begin{array}{l}\text { Seed } \\
\text { size }\end{array}$ \\
\hline 1 & Determinant 2 & Giza 843 x D5 & $S$ & Medium & Light brown (B.H) & Medium \\
\hline 2 & Determinant 5 & Nubaria1 x D6 & $\mathrm{R}$ & Early & Light brown (B.H) & Medium \\
\hline 3 & Determinant 8 & Giza 843 x D8 & MR & Medium & Light brown (B.H) & Medium \\
\hline 5 & Giza 40 & Selection from Rebaya 40 & H.S & Early & Light brown (B.H) & Small \\
\hline
\end{tabular}

${ }^{*}$ Reaction for chocolate spot: R= Resistant, M.R = Moderate resistant, S= Susceptible and H.S = highly susceptible.

B. $\mathrm{H}=$ Black Hilum

$\mathrm{M}=$ Mean $=\overline{\mathrm{F}} 2$

$\mathrm{A}=2 \overline{\mathrm{B}} \mathrm{c} 1-\overline{\mathrm{P}}_{1}-\overline{\mathrm{F}}_{1}$

$\mathrm{B}=2 \overline{\mathrm{BC}}_{2}-\overline{\mathrm{P}}_{2}-\overline{\mathrm{F}}_{1}$

$C=4 \bar{F}_{2}-2 \bar{F} 1-\bar{P}_{1}-\bar{P}_{2}$

$\mathrm{D}=2 \overline{\mathrm{F}}_{2}-\overline{\mathrm{BC}}_{1}-\overline{\mathrm{BC}}_{2}$ and

$\mathrm{V}(\mathrm{A})=4 \sigma^{2}\left(\overline{\mathrm{BC}}_{1}\right)+\mathrm{V}\left(\overline{\mathrm{P}}_{1}\right)+\mathrm{V}\left(\overline{\mathrm{F}}_{1}\right)$

$\mathrm{V}(\mathrm{B})=4 \mathrm{~V}\left(\overline{\mathrm{B}} \mathrm{C}_{2}\right)+\mathrm{V}\left(\overline{\mathrm{P}_{2}}\right)+\mathrm{V}\left(\overline{\mathrm{F}_{1}}\right)$

$\mathrm{V}(\mathrm{C})=16 \mathrm{~V}\left(\overline{\mathrm{F}}_{2}\right)+4 \mathrm{~V}\left(\overline{\mathrm{F}}_{1}\right)+\mathrm{V}\left(\overline{\mathrm{P}}_{1}\right)+\mathrm{V}\left(\overline{\mathrm{P}}_{2}\right)$

$\mathrm{V}(\mathrm{D})=4 \mathrm{~V}\left(\overline{\mathrm{F}}_{2}\right)+\mathrm{V}\left(\overline{\mathrm{B}}_{1}\right)+\mathrm{V}\left(\overline{\mathrm{BC}}_{2}\right)$

The standard error of $A, B, C$ and $D$ is obtained by taking the square root of their respective variances. t-test values were calculated by dividing the effects of $A, B, C$ and $D$ on their respective standard error. Generation means were analyzed using the procedure of Gamble (1962) for estimation and separation of gene effects involved in the inheritance of yield and its components into six parameters. Jinks and Jones (1958) gave six parameters model for estimation of variosgenetic components

S.E $A=(V A)^{1 / 2}$

S.E $B=(V B)^{1 / 2}$

S.E C $=(V C)^{1 / 2}$

S.E D $=(V D)^{1 / 2}$

The ( $t$ ) values are calculated as follows:

"t" A = A/ S.E (A)

"t" B = B/ S.E (B) "t" C = C/ S.E(C)

"t" D = D/ S.E(D)

The calculated values of " $\mathrm{t}$ " were compared with tabulated value of $t$ at $5 \%$ and $1 \%$ levels of probability. In each test, the degrees of freedom ( $d f$ ) are sum of $(d f)$ of various generations involved.

The significance of A and B scales indicate the presence of all types of nonallelic gene interactions. The significance of C scale suggests ( $d$ d) types of epistasis.

\section{Gene action (types of gene effect):}

Data were analyzed by generation mean analysis method as follows: The means of the six populations in each cross were used to estimate the six parameters of gene effects, using the Gamble's procedure (1962):

where, the parameters $\mathrm{m}, \mathrm{a}, \mathrm{d}, \mathrm{aa}, \mathrm{ad}$ and dd refer to mean effects, additive, dominance, additive $x$ additive, additive $x$ dominance and dominance $x$ dominance gene effects, respectively. Estimates of gene effects were tested for significant difference from zero by using $\mathrm{t}$ - test as follaws :

Calculated $t=$ Effect $/(\text { variance of effect })^{1 / 2}$

Tabulated ( $\mathrm{t}$ ) was defined with d.f at 0.05 and 0.01 level of probability, where the variance of an effect is a linear function of variance of its mean.

Genetic analysis was done using means and the variance for $\mathrm{P}_{1}, \mathrm{P}_{2}, \mathrm{~F}_{1}, \mathrm{Bc}_{1}, \mathrm{Bc}_{2}$ and $F_{2}$ populations. $A, B, C$ and $D$ scaling tests 
of Mather (1949) were used to test the adequacy of the additive-dominance model and also, to study the non-allelic interaction. The Gamble (1962) procedure's was used to estimate the genetic variance of generation mean and gene action (type of gene effects). The variance of each of the genetic variance components was estimated as linear function of the variance of the mean squares.

Expected values of genetic advance (G a) was calculated according to Johanson et al. (1955), where, using the selection differential $(K)$ equal 2.06 for $5 \%$ selection intensity where,

$\mathrm{Ga}=\mathrm{K} \times \mathrm{h}^{2} \times\left(\mathrm{VF}_{2}\right)^{1 / 2}$

Prediction of genetic advance as percentage of the $F_{2}$ mean ( $G$ a \%) was estimated as given by Miller et al, (1958).

$\mathrm{Ga} \%=\mathrm{Ga} / \overline{\mathrm{X}} * 100$

\section{Heterosis (\%):}

The variance of a mean square was calculated as given by (Anderson and Bancroft (1952) and estimates the heritability. Heterosis and percentage of inbreeding depression (I.D \%) were measured according (Mather and Jinks, 1971). The nature and type of dominance were determined by means of potence ratio method $(P)$ which can be defined according (Smith, 1952).

Mid parent heterosis $(\bar{M} \cdot \bar{P})=\left(\bar{F}_{1}-\overline{M P}\right) / \overline{M P} * 100$

Better parent heterosis $(\overline{B . P})=(\bar{F} 1-B \bar{P}) / B \bar{P} * 100$

To test the significance of the above estimate of heterosis, the variance of heterosis deviation was calculated as a linear function of three variances.

Variances of heterosis over mid- parent deviation $=V F_{1}+1 / 4 V p_{1}+1 / 4 V P_{2}$

Variances of heterosis over mid- parent deviation $=\mathrm{VF}_{1}+\mathrm{VB} . \mathrm{P}$

S.E for mid parental heterosis

$\overline{\mathrm{F}}_{1}-\overline{\mathrm{MP}}=\left\{\overline{\mathrm{V}}_{1}+1 / 4 \overline{\mathrm{VP}}_{1}+1 / 4 \overline{\mathrm{V}}_{2}\right\}^{1 / 2}$
S.E for better parental heterosis

$\overline{\mathrm{F}}_{1}-\overline{\mathrm{B}} \cdot \mathrm{P}=\left(\overline{\mathrm{VF}}_{1}+\mathrm{VB \textrm {BP } _ { 1 }}\right)^{1 / 2}$

\section{Inbreeding depression (I.D):}

$I . D=\left(\bar{F} 1-\bar{F}_{2}\right) / \bar{F}_{1} \times 100$

and S.E for inbreeding depression

$\left(\bar{F}_{1}-\bar{F}_{2}\right)=\left(V \bar{F}_{1}+V \bar{F}_{2}\right)^{1 / 2}$

\section{Potence ratio}

Potence ratio (P.R) was calculated according to Wigan (1944) and Mather and Jinks (1971)

P.R $=\overline{\mathrm{F}} 1-\overline{\mathrm{M}} \mathrm{P} / 1 / 2(\overline{\mathrm{HP}}-\mathrm{L} \overline{\mathrm{P}})$

Where: $F_{1}=$ Mean of the $F_{1}$ performance.

M.P = Mid-Parent value $=P 1+P 2 / 2$.

H. $p=$ The hiegher parent value.

L. $P=$ The lower parent value.

Absence of dominance is consider when (p) is zero, and partial dominanance is assumed when ( $p$ ) is between +1 and -1 but not equal zero complete dominance is considered when $(P)$ is equal +1 or -1 and over-dominance is considered when $(P)$ is $>$ +1 or $<-1$.

Broad sense heritability (H) for $F_{2}$ generation was estimated based on the equation.

$\mathrm{H}=\mathrm{VG} / \mathrm{Vph} * 100$
$\mathrm{~h}^{2}=\mathrm{VA} / \mathrm{Vph} * 100$

The environmental variance $\left(V_{E}\right)$ and genetic variance $\left(V_{G}\right)$ were estimated according to Mansur et al. (1993) as follows:

$\mathrm{V}_{\mathrm{G}}=\mathrm{VF}_{2}-\mathrm{V}_{\mathrm{E}}$

$V_{E}=n_{e}-1\left(n p_{1} V_{1}+n p_{2} \bigvee_{p 2}+n F_{1} V_{F_{1}}\right)$

where: $n e=n p_{1}+n p_{2}+n F_{1}$ and $n p_{1}, n_{2}$ and $\mathrm{nF}_{1}$ are the number of plants in the $\mathrm{P}_{1}$, $P_{2}$ and $F_{1}$ generations in each cross, respectively.

Narrow-sense heritability $\left(h^{2}\right)$ for $F_{2}$ generation was estimated as proposed by Warner (1952) where:

$\mathrm{h}^{2}=2 \mathrm{VF} 2-\left(\mathrm{VBC}_{1}+\mathrm{VBC}_{2}\right) / \mathrm{VF} 2 * 100$

Phenotypic variance (total variance) $=\mathrm{VF}_{2}$ 
The genotypic coefficient of variation (G.C.V \%) was estimated as the formulae developed by Burton (1952).

\section{RESULTS AND DISCUSSION}

The difference between each two parents was found to be significant in all studied traits in the three crosses as presented in Table (2) which showed the mean performance, variance and mean variance for the six populations of the crosses of different traits. Significant differences were observed among most genotypes for the measured traits. The parental genotypes could be arranged into two groups, the first group included the genotypes of D2, D5 and D8, which are considered to be determinate with low yielding ability. The second group included Giza 40 which is susceptible to chocolate spot, accompanied with high yielding ability. In general, the first cross was the earliest cross and recorded (44.33 days) for $\mathrm{BC}_{1}$ and third cross recorded (50.67 days) for $F_{1}$. The tallest plants were recorded $(139 \mathrm{~cm})$ for $F_{1}$ in the first cross. $P_{2}$ had the highest number of branches / plant (9.20 and 8.40) in the first and second crosses, respectively. The number of pods / plant recorded (46.03 and 65.33) in the $F_{1}$ of the first and second crosses and in the $F_{2}$ (52.94) in the third cross. The mean number of seeds / plant of $F_{1}$ population in the first and second crosses were (126.73 and 157.67), respectively. The $F_{2}$ of the thirdrd cross produced (141.61) that was the highest mean number of seeds / plant. Also, the $F_{1}$ of the first and second crosses recorded mean seed yield / plant of $(97.21 \mathrm{~g}$ and $141.65 \mathrm{~g}$ ), respectively, while the $F_{2}$ of the third cross produced mean seed yield I plant of $(117.76 \mathrm{~g})$. The $F_{1}$ of the second and third crosses recorded highest mean100-seed weight of (88.88 $\mathrm{g}$ and 96.23 $\mathrm{g}$ ), respectively, while the $\mathrm{BC}_{2}$ of the third cross produced mean100 - seed weight of (81.92 g).

Tests for scale and genetically analysis of generation means to give estimates of additive (a), dominance (d) and the three epistatic effects additive $x$ additive (aa), additive $x$ dominance $(\mathrm{ad})$ and dominance $x$ dominance (dd) according to the relationships illustrated by Gamble (1962) are presented in Table (3). Scaling test was significantly differed from zero for all traits in all crosses, indicating the presence of all types of non-allelic interactions (Mather, 1949). The estimated mean effects ( $m$ ), which reflects the contribution due to the over-all mean plus the locus effects and interaction of the fixed loci that were highly significant for all traits in the all crosses, indicating that these traits were quantitatively inherited.

Additive gene effect (a) was positive and highly significant for plant height in the three crosses and number of pods / plant, number of seeds / plant, 100 - seed weight and seed yield / plant in the second cross. Meanwhile, negative and highly significant (a) effect was found for number of branches / plant in the three crosses, and flowering date and $100-$ seed weight in the first cross, number of pods plant ${ }^{-1}$, number of seeds / plant and seed yield / plant in the second cross. These results indicated that, improving the performance of these traits by selection in early segregating generations may be more effective using the pedigree selection method, El-Hady et al (2009).

The dominance gene effects (d) were positive and highly significant for number of pods / plant, number of seeds / plant and seed yield / plant in the first and second cross and plant height, number of branches / plant and100 - seed weight in the first, third and second crosses, respectively. The estimates of dominance effects (d) were negatively highly significant for flowering date in the three crosses, and plant height in the second and third crosses, and number of pods / plant, number of seeds / plant and seed yield / plant in the third cross. These results indicated the important role of dominance gene effects in the inheritance of these traits. On the other hand, significance of additive (a) and dominance (d) 
components indicated that both additive and dominance gene effects are important in the inheritance of these traits. These significant and higher values in magnitude of (d) than that of additive type for all studied traits, except for number of branches / plant, indicated the important role of dominance gene effects in the inheritance of these traits. Also, selecting desirable characters would be effective in the late segregating generations. Similar conclusion was obtained in faba bean by El -Hosary (1981), El - Refaey (1987), Hendawy (1994) and El -Hady et al (2009).

Table (2): Mean performance $(\bar{X})$, variance $\left(S^{2}\right)$ and variance of mean $\left(S^{2} \bar{X}\right)$ for the six populations of the three crosses for different trait.

\begin{tabular}{|c|c|c|c|c|c|c|c|c|}
\hline Trait & Cross & $\begin{array}{l}\text { Statistical } \\
\text { Parameter }\end{array}$ & $P_{1}$ & $P_{2}$ & $F_{1}$ & $F_{2}$ & $\mathrm{BC}_{1}$ & $\mathrm{BC}_{2}$ \\
\hline \multirow{10}{*}{$\begin{array}{l}\text { Flowering } \\
\text { date (day) }\end{array}$} & \multirow{4}{*}{1} & No.of plants & 30 & 30 & 30 & 300 & 75 & 75 \\
\hline & & $\bar{X}$ & 56.67 & 66.67 & 52.50 & 51.38 & 44.33 & 57.07 \\
\hline & & $S^{2}$ & 2.75 & 2.20 & 3.47 & 35.09 & 28.33 & 27.25 \\
\hline & & $S^{2} \bar{x}$ & 0.09 & 0.07 & 0.11 & 0.11 & 0.37 & 0.36 \\
\hline & \multirow{3}{*}{2} & $\overline{\mathrm{X}}$ & 58.00 & 53.67 & 56.83 & 57.08 & 53.47 & 53.13 \\
\hline & & $S^{2}$ & 3.21 & 2.06 & 3.01 & 31.35 & 25.39 & 26.93 \\
\hline & & $S^{2} \bar{x}$ & 0.10 & 0.06 & 0.10 & 0.10 & 0.33 & 0.35 \\
\hline & \multirow{3}{*}{3} & $\overline{\mathrm{X}}$ & 56.67 & 63.67 & 50.67 & 52.95 & 52.33 & 51.40 \\
\hline & & $S^{2}$ & 1.75 & 1.96 & 1.99 & 33.26 & 29.68 & 26.92 \\
\hline & & $S^{2} \bar{x}$ & 0.05 & 0.06 & 0.06 & 0.11 & 0.39 & 0.35 \\
\hline \multirow{9}{*}{$\begin{array}{l}\text { Plant } \\
\text { height }(\mathrm{cm})\end{array}$} & \multirow{3}{*}{1} & $\bar{X}$ & 132.27 & 62.33 & 139.00 & 121.40 & 134.87 & 120.33 \\
\hline & & $S^{2}$ & 6.34 & 9.20 & 7.28 & 148.10 & 128.26 & 135.77 \\
\hline & & $\mathrm{S}^{2} \overline{\mathrm{x}}$ & 0.21 & 0.30 & 0.24 & 0.49 & 1.71 & 1.81 \\
\hline & \multirow{3}{*}{2} & $\bar{X}$ & 134.33 & 93.20 & 114.17 & 138.24 & 132.87 & 123.67 \\
\hline & & $S^{2}$ & 8.30 & 7.54 & 6.21 & 158.93 & 150.17 & 144.82 \\
\hline & & $S^{2} \bar{x}$ & 0.27 & 0.25 & 0.20 & 0.52 & 2.00 & 1.93 \\
\hline & \multirow{3}{*}{3} & $\bar{X}$ & 132.67 & 99.67 & 113.17 & 135.32 & 134.33 & 115.13 \\
\hline & & $S^{2}$ & 8.81 & 6.99 & 8.59 & 165.70 & 159.01 & 137.55 \\
\hline & & $S^{2} \bar{x}$ & 0.29 & 0.23 & 0.28 & 0.55 & 2.12 & 1.83 \\
\hline \multirow{9}{*}{$\begin{array}{l}\text { No. of } \\
\text { branches/ } \\
\text { plant }\end{array}$} & \multirow{3}{*}{1} & $\overline{\mathrm{X}}$ & 5.27 & 9.20 & 5.80 & 5.11 & 4.63 & 6.91 \\
\hline & & $S^{2}$ & 1.51 & 1.72 & 2.03 & 25.80 & 22.91 & 22.17 \\
\hline & & $\mathrm{S}^{2} \overline{\mathrm{X}}$ & 0.05 & 0.05 & 0.06 & 0.08 & 0.30 & 0.29 \\
\hline & \multirow{3}{*}{2} & $\overline{\mathrm{X}}$ & 4.87 & 6.93 & 5.30 & 5.19 & 4.72 & 7.61 \\
\hline & & $\mathrm{S}^{2}$ & 1.15 & 1.86 & 2.63 & 26.78 & 22.93 & 24.97 \\
\hline & & $S^{2} \bar{x}$ & 0.03 & 0.06 & 0.08 & 0.08 & 0.30 & 0.33 \\
\hline & \multirow{3}{*}{3} & $\overline{\mathrm{X}}$ & 4.93 & 8.40 & 6.77 & 3.52 & 4.48 & 8.03 \\
\hline & & $S^{2}$ & 1.72 & 1.14 & 1.50 & 29.28 & 25.31 & 27.59 \\
\hline & & $S^{2} \bar{x}$ & 0.05 & 0.03 & 0.05 & 0.09 & 0.33 & 0.36 \\
\hline
\end{tabular}


Table (2): Cont.

\begin{tabular}{|c|c|c|c|c|c|c|c|c|}
\hline Trait & Cross & $\begin{array}{l}\text { Statistical } \\
\text { Parameter }\end{array}$ & $\mathrm{P}_{1}$ & $\mathrm{P}_{2}$ & $F_{1}$ & $F_{2}$ & $\mathrm{BC}_{1}$ & $\mathrm{BC}_{2}$ \\
\hline \multirow{10}{*}{$\begin{array}{l}\text { No. of } \\
\text { pods/ plant }\end{array}$} & \multirow{4}{*}{1} & No. of plants & 30 & 30 & 30 & 300 & 75 & 75 \\
\hline & & $\overline{\mathrm{X}}$ & 44.00 & 16.80 & 46.03 & 27.40 & 40.32 & 30.23 \\
\hline & & $\mathrm{S}^{2}$ & 8.28 & 6.72 & 4.24 & 138.68 & 121.06 & 132.12 \\
\hline & & $S^{2} \bar{X}$ & 0.27 & 0.22 & 0.14 & 0.46 & 1.61 & 1.76 \\
\hline & \multirow{3}{*}{2} & $\overline{\mathrm{X}}$ & 44.73 & 15.53 & 65.33 & 39.80 & 34.44 & 42.25 \\
\hline & & $\mathrm{S}^{2}$ & 4.20 & 7.02 & 4.06 & 148.64 & 127.82 & 132.65 \\
\hline & & $S^{2} \bar{x}$ & 0.14 & 0.23 & 0.13 & 0.49 & 1.70 & 1.76 \\
\hline & \multirow{3}{*}{3} & $\overline{\mathrm{X}}$ & 44.60 & 13.57 & 35.17 & 52.94 & 30.37 & 29.49 \\
\hline & & $S^{2}$ & 7.49 & 4.84 & 8.76 & 212.62 & 193.32 & 173.79 \\
\hline & & $S^{2} \bar{x}$ & 0.24 & 0.16 & 0.29 & 0.70 & 2.57 & 2.31 \\
\hline \multirow{9}{*}{$\begin{array}{l}\text { No. of seed } \\
\text { / plant }\end{array}$} & \multirow{3}{*}{1} & $\overline{\mathrm{X}}$ & 119.43 & 50.00 & 126.73 & 73.25 & 109.76 & 89.25 \\
\hline & & $S^{2}$ & 7.53 & 8.31 & 6.41 & 207.66 & 164.16 & 187.79 \\
\hline & & $S^{2} \bar{x}$ & 0.25 & 0.27 & 0.21 & 0.69 & 2.18 & 2.50 \\
\hline & \multirow{3}{*}{2} & $\overline{\mathrm{X}}$ & 119.70 & 38.50 & 157.67 & 112.93 & 86.48 & 130.05 \\
\hline & & $S^{2}$ & 6.49 & 8.95 & 8.16 & 231.55 & 187.98 & 171.11 \\
\hline & & $S^{2} \bar{x}$ & 0.21 & 0.29 & 0.27 & 0.77 & 2.50 & 2.28 \\
\hline & \multirow{3}{*}{3} & $\overline{\mathrm{X}}$ & 119.53 & 37.23 & 99.53 & 141.61 & 79.53 & 81.69 \\
\hline & & $S^{2}$ & 9.29 & 7.01 & 8.71 & 191.06 & 174.36 & 136.73 \\
\hline & & $S^{2} \bar{x}$ & 0.30 & 0.23 & 0.29 & 0.63 & 2.32 & 1.82 \\
\hline \multirow{9}{*}{$\begin{array}{l}\text { Seed yield/ } \\
\text { plant }(\mathrm{g})\end{array}$} & \multirow{3}{*}{1} & $\bar{X}$ & 79.72 & 38.81 & 97.21 & 58.88 & 79.15 & 73.69 \\
\hline & & $S^{2}$ & 6.18 & 9.76 & 7.73 & 118.12 & 82.84 & 95.63 \\
\hline & & $S^{2} \bar{x}$ & 0.20 & 0.32 & 0.25 & 0.39 & 1.10 & 1.27 \\
\hline & \multirow{3}{*}{2} & $\overline{\mathrm{X}}$ & 82.07 & 24.50 & 141.65 & 82.73 & 68.62 & 84.84 \\
\hline & & $\mathrm{S}^{2}$ & 7.91 & 8.98 & 7.52 & 179.37 & 168.23 & 159.06 \\
\hline & & $S^{2} \bar{x}$ & 0.26 & 0.29 & 0.25 & 0.59 & 2.24 & 2.12 \\
\hline & \multirow{3}{*}{3} & $\overline{\mathrm{X}}$ & 79.81 & 31.35 & 95.95 & 117.76 & 60.47 & 65.15 \\
\hline & & $S^{2}$ & 5.83 & 7.21 & 7.60 & 179.15 & 148.81 & 151.95 \\
\hline & & $S^{2} \bar{x}$ & 0.19 & 0.24 & 0.25 & 0.59 & 1.98 & 2.02 \\
\hline \multirow{9}{*}{$\begin{array}{l}\text { 100-seed } \\
\text { weight }(\mathrm{g})\end{array}$} & \multirow{3}{*}{1} & $\overline{\mathrm{X}}$ & 65.26 & 76.56 & 77.32 & 78.10 & 72.64 & 81.92 \\
\hline & & $\mathrm{S}^{2}$ & 6.65 & 7.95 & 7.20 & 130.53 & 96.05 & 108.53 \\
\hline & & $S^{2} \bar{x}$ & 0.22 & 0.26 & 0.24 & 0.43 & 1.28 & 1.44 \\
\hline & \multirow{3}{*}{2} & $\overline{\mathrm{X}}$ & 67.68 & 64.10 & 88.88 & 74.75 & 78.76 & 81.16 \\
\hline & & $S^{2}$ & 6.75 & 5.36 & 5.83 & 108.08 & 89.88 & 93.31 \\
\hline & & $S^{2} \bar{x}$ & 0.22 & 0.17 & 0.19 & 0.36 & 1.19 & 1.24 \\
\hline & \multirow{3}{*}{3} & $\overline{\mathrm{X}}$ & 65.36 & 85.75 & 96.23 & 83.68 & 78.61 & 79.50 \\
\hline & & $S^{2}$ & 9.82 & 8.66 & 6.78 & 189.93 & 167.93 & 175.24 \\
\hline & & $S^{2} \bar{x}$ & 0.32 & 0.28 & 0.22 & 0.63 & 2.23 & 2.33 \\
\hline
\end{tabular}

I (Giza40 x Detriment 2) - II (Giza40 x Detriment 5) - III (Giza40 x Detriment 8) 


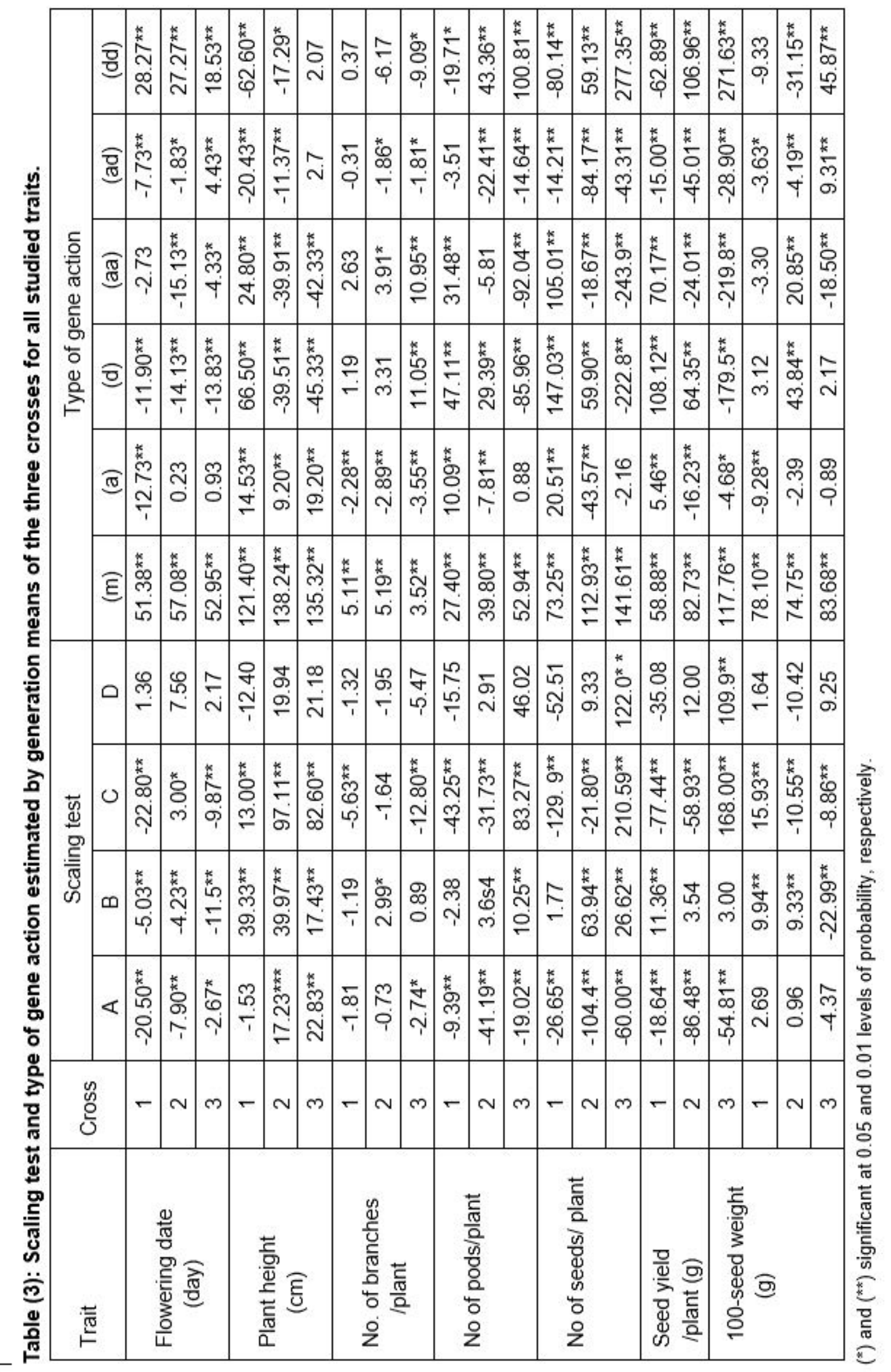


However, It could be observed that, the significant additive $x$ additive type of gene effects appeared to be contributed more to the performance of yield and the studied yield components than do the significant additive $x$ dominance and dominance $x$ dominance gene effects. However, the additive $x$ additive gene effects were relatively more important than the additive effects but generally, less important than the dominance effects. Moreover, the (dd) gene effects were more important and higher in magnitude than (aa) epistatic effects in the inheritance of all studied traits in all crosses, except for plant height in the second and third crosses, number of branches / plant and seed yield / plant in the first cross, indicating that the selection would be fruitful if delayed till dominance and its epistatic effects are reduced to the minimum and resulted in the slow- down progress of selection. However, the (aa) and (dd) gene effects are mostly negative in most cases giving diminishing effects which apparently are an undesirable form of epistasis, where the alleles responsible for less value of traits were over dominant over the alleles controlling high value. While (ad) gene effects were mostly positive, indicating enhancing effects on performance of the trait (s) in question. The parameter ad (epistatic gene interaction) was significant and positive or negative for the studied traits in all crosses, except for plant height in the third cross, number of branches / plant and number of pods / plant in the cross1, indicating that dominance was towards direction of increasing and decreasing, respectively for the unexpected traits. The type of gene action reported by Singh et al (1987) in field peas, El-Hosary (1981), Hendawy (1994) Attia et al. (2007) and El Hady et al. (2009) in faba bean were rather confirmed by the type of variation found in the present study. El-Refaey et al., (2015) found similar conclusion in barley.

\section{Heterosis:}

The phenomenon of heterosis (hybrid vigour) is of common occurrence in both cross and self- pollinated crops. Faba bean which is often a self-fertilized crop also shows hybrid vigour when hybridization takes place between homozygous varieties. There are three important genetic factors affecting heterosis; (a) the genetic diversity of the parents, where the heterotic effects increased with the increase of the genetic divergence in morphological characters with respect to geographical origin of parents, (b) the genetic base of the parents and (c) the wider adaptability of the parents.

Heterosis over mid and better parents, potence ratio and inbreeding depression for all traits of the three crosses are shown in Table (4) which indicated that, highly significant heterosis over mid and better parents in favourable direction for all traits, except for plant height in the second cross (Detriment $5 \times$ Giza 40) and 100-seed weight in the first cross.

Highly significant positive heterotic effect values was obtained for yield and its components in the three crosses over the mid-parent Negative and highly significant heterosis was obtained for flowering date in the first and third crosses, plant height in the third cross and number of branches / plant in the first and second crosses. These heterotic effects were due to over dominance towards the higher parent $(P>$ +1 ) for most traits concerning yield and its components in the three crosses. On the other hand, the values of this parameter were less than unity but not equal zero in the third cross for number of branches / plant, number of pods per pant and number of seeds / plant, indicating partial dominance. These results are in agreement with those reported by Abdalla (1977), Abdalla and Fischbeck (1983), Hendawy (1994), El - Hosary et al. (1997); El-Hady et al. (1998), Toker ( 2004), Attia et al. (2006) and El-Refaey et al. (2017).

Highly significant positive heterosis over better - parent was obtained for number of pods / plant, number of seeds / plant in the first and second cross, seed yield / plant in the three crosses, 100-seed weight in the 
second and third crosses and plant height in the first cross. Meanwhile, negative and highly significant heterosis over better parent was obtained for flowering date in first and third crosses. The differences in heterosis percent might be due to genetic variability of the parents and for non-allelic interactions, which can either increase or decrease the expression of heterosis. Even in the absence of epistasis, multiple alleles at a locus could lead to either positive or negative heterosis (Cress, 1966).

\section{Inbreeding depression:}

The inbreeding depression, measures the extent of reduction of the $\mathrm{F}_{2}$ generation due to inbreeding. It was significant and /or highly significant in positive direction for number of branches /plant in the first and third crosses, number of seeds / plant in the first cross, number of pods / plant and seed yield/plant in the first and second crosses. Both heterosis and inbreeding depression are coinciding to the same particular phenomenon. Therefore, it is logical to anticipate that heterosis in the $\mathrm{F}_{1}, \mathrm{~s}$ will be followed by an appreciable reduction in the $\mathrm{F}_{2}$ performance. Also, reduction in values of non- additive genetic components is expected caused by means of inbreeding depression. The obtained results herein were in agreement with this anticipation. These results are in harmony with those reported by Abdalla ( 1977), Abdallah and Fischbeck (1983), El- Refaey and Radi (1991), Hendawy (1994), El - Hosary et al. 1997; El-Hady et al. (1998), Toker ( 2004), Attia et al. (2006) El-Hady et al. (2009) El Refaey et al. ( 2015) and El-Refaey et al. (2017).

Table (4): Heterosis, inbreeding depression (ID) and potence ratio in the three crosses for all studied traits.

\begin{tabular}{|c|c|c|c|c|c|}
\hline \multirow{2}{*}{ Traits } & \multirow{2}{*}{ Crosses } & \multicolumn{3}{|c|}{ Heterosis (\%) } & \multirow{2}{*}{$\begin{array}{c}\text { Inbreeding } \\
\text { depression } \\
\text { (ID) }\end{array}$} \\
\hline & & M.P & PR & B.P & \\
\hline \multirow{3}{*}{ Flowering date } & 1 & $-14.86^{\star *}$ & -1.83 & $-7.35^{\star \star}$ & 2.13 \\
\hline & 2 & $1.79 * *$ & 0.46 & $5.90 * \star$ & -0.44 \\
\hline & 3 & $-15.79 * \star$ & -2.71 & $-10.59 * \star$ & -4.51 \\
\hline \multirow{3}{*}{ Plant height $(\mathrm{cm})$} & 1 & $42.86^{\star \star}$ & 1.19 & $5.09^{\star \star}$ & 12.66 \\
\hline & 2 & 0.35 & 0.02 & $-15.01^{* *}$ & -21.09 \\
\hline & 3 & $-2.58^{\star \star}$ & -0.18 & $-14.70 * \star$ & -19.57 \\
\hline \multirow{3}{*}{ No of branches/plant } & 1 & $-19.82^{\star \star}$ & -0.73 & $-36.96^{\star \star}$ & $11.90^{*}$ \\
\hline & 2 & $-10.17^{\star \star}$ & -0.58 & $-23.56^{* *}$ & 2.08 \\
\hline & 3 & 1.50 ** & 0.06 & $-19.44^{\star \star}$ & $48.03^{\star \star}$ \\
\hline \multirow{3}{*}{ No of Pods/plant } & 1 & $51.43^{\star \star}$ & 1.15 & $4.62^{\star \star}$ & $40.47^{\star *}$ \\
\hline & 2 & $116.81^{\star \star}$ & 2.41 & $46.05^{\star \star}$ & $39.08^{\star \star}$ \\
\hline & 3 & $20.92^{\star \star}$ & 0.39 & $-21.15^{\star \star}$ & $-50.55^{\star *}$ \\
\hline \multirow{3}{*}{ No of seeds/plant } & 1 & $49.60^{\star \star}$ & 1.21 & $6.11^{\star *}$ & $42.20^{\star *}$ \\
\hline & 2 & $99.33^{\star \star}$ & 1.94 & $31.72^{\star \star}$ & 28.37 \\
\hline & 3 & $26.98^{\star *}$ & 0.51 & $-16.73^{\star *}$ & $-42.27^{\star \star}$ \\
\hline \multirow{3}{*}{ Seed yield/plant (g) } & 1 & $64.03^{\star *}$ & 1.85 & $21.94^{\star *}$ & $39.43^{\star *}$ \\
\hline & 2 & $165.83^{\star \star}$ & 3.07 & $72.60^{\star *}$ & $41.59^{\star \star}$ \\
\hline & 3 & $72.62^{\star \star}$ & 1.67 & $20.22^{\star \star}$ & -22.74 \\
\hline \multirow{3}{*}{ 100-seed weight (g) } & 1 & $9.04^{* *}$ & 1.13 & 0.99 & -1.00 \\
\hline & 2 & $34.89^{\star \star}$ & 12.83 & $31.32^{\star \star}$ & 15.90 \\
\hline & 3 & $27.36^{\star \star}$ & 2.03 & $12.22^{\star \star}$ & 13.04 \\
\hline
\end{tabular}




\section{Heritability:}

Heritability in broad and narrow senses expected and predicted genetic advances and phenotypic and genotypic coefficients of variations for the studied traits are presented in Table 5. It could be observed that, heritability values in the broad-sense were generally higher than the corresponding values of narrow-sense in all crosses for all studied traits. Moreover, the estimated values of heritability in broad and narrowsenses of the crosses differed from one to another. However, high heritability values in broad sense were detected in all crosses. The highest broad sense heritability was obtained for number of pods/plant (96.75\%) and number of seeds/plant (96.57), in the second cross. Meanwhile, the lowest estimates were resulted for flowering date in the first and second crosses with values of $91 \%$ and $91.53 \%$, respectively. Heritability in narrow sense as estimated using $F_{2}$ and backcross data was low for plant height in the second cross with value of $(14.39 \%)$ and seed yield / plant (17.53\%), in the same cross, respectively. indicating that these traits were influenced by non-heritable effects, i.e. dominance and/or environment. This again confirmed the obtained results of gen action where the inheritances of these traits were due mainly to dominance gene effects. While, high narrow sense values were detected for seed yield /plant in the first cross (48.91\%) and number of seeds /plant in the second cross (44.92\%) 100seed weight in the first cross (43.27\%) and flowering date in the first cross (41.61\%). This revealed that, the additive genetic variance played an important role in the existence of variability in these cases. These results are in agreement with those reported by El-Hady et al. (1997), Kalia and Sood (2004), Attia et al. (2006) Al-Ghamdi (2007) El-Galaly et al. (2008) and El-Refaey et al. (2017).

\section{Genetic advance:}

The genetic coefficient of variability together with the heritability estimates would seem to give the best picture of the amount of genetic advance to be expected from selection (Swarup and Chaugale, 1962). From these points of view, genetic gain upon selecting the top $5 \%$ of the $F_{2}$ population for the studied characters is presented in Table 5. Number of branches / plant and number of pods / plant in all crosses, number of seeds / plant in two crosses exhibited high PCV\% and GCV\% and genetic advance with high heritability indicating additive gene effects controlled the improvement of these traits.

The highest predicted genetic advance as mean percent ( $\mathrm{Ga} \%$ ) were detected for number of branches plant in three crosses (51.75, 43.41 and 61.27\%), respectively. While low genetic advance values were obtained for flowering date, plant height, number of seeds / plant, seed yield / plant and 100-seed weight in the all crosses under study. Johanson et al. (1955) reported that heritability estimates along with genetic advance are usually more useful than the heritability values alone in predicting the results of selecting the best individuals. In the present work, high genetic advance was associated with high heritability values in narrow sense for number of branches I plant, number of pods / plant and 100- seed weight in the three crosses.

Therefore, selection in these populations may be effective and satisfactory in the early segregating generations (El -Hady et al 2009). Also, moderate and low heritability estimates were associated with moderate and low predicted genetic advance for plant height in the second and third crosses, seed yield / plant in the second cross and 100seed weight in the third cross. Thus, it could be suggested that, the selection for faba bean seed yield in subsequent generations will be relatively more effective than in the early $F_{2}$ generation. 
Table (5): Heritability percentage in broad $(H)$, narrow $\left(h^{2}\right)$ senses, Phenotypic $(P C V)$ and genotypic (GCV) coefficient of variation and expected genetic advance from selection $(\mathrm{Ga})$ of the three crosses for all studied traits.

\begin{tabular}{|c|c|c|c|c|c|c|c|}
\hline \multirow[b]{2}{*}{ Traits } & \multirow[b]{2}{*}{ Crosses } & \multicolumn{2}{|c|}{ Heritability } & \multirow[b]{2}{*}{ PCV\% } & \multirow[b]{2}{*}{ GCV\% } & \multicolumn{2}{|c|}{ Genetic advance } \\
\hline & & $\mathrm{H}$ & $\mathrm{h}^{2}$ & & & Ga & Ga \% \\
\hline \multirow{3}{*}{ Flowering date (day) } & 1 & 91.53 & 41.61 & 11.53 & 11.06 & 5.08 & 9.88 \\
\hline & 2 & 91.00 & 33.10 & 9.81 & 9.37 & 3.82 & 6.69 \\
\hline & 3 & 94.22 & 29.83 & 10.89 & 10.58 & 3.54 & 6.69 \\
\hline \multirow{3}{*}{ Plant height $(\mathrm{cm})$} & 1 & 94.92 & 21.72 & 10.02 & 9.76 & 5.45 & 4.49 \\
\hline & 2 & 95.55 & 14.39 & 9.12 & 8.91 & 3.74 & 2.70 \\
\hline & 3 & 95.02 & 21.03 & 9.51 & 9.27 & 5.58 & 4.12 \\
\hline \multirow{3}{*}{ No of branches/plant } & 1 & 92.94 & 25.27 & 99.39 & 95.89 & 2.64 & 51.75 \\
\hline & 2 & 92.27 & 21.14 & 99.71 & 96.15 & 2.25 & 43.41 \\
\hline & 3 & 95.00 & 19.33 & 153.72 & 149.87 & 2.15 & 61.27 \\
\hline \multirow{3}{*}{ No of Pods/plant } & 1 & 95.77 & 17.44 & 42.98 & 41.97 & 4.23 & 15.44 \\
\hline & 2 & 96.75 & 24.76 & 30.63 & 30.104 & 6.22 & 15.63 \\
\hline & 3 & 96.49 & 27.34 & 27.54 & 27.08 & 8.21 & 15.51 \\
\hline \multirow{3}{*}{ No of seeds/plant } & 1 & 96.55 & 30.52 & 19.67 & 19.32 & 9.06 & 12.37 \\
\hline & 2 & 96.57 & 44.92 & 13.47 & 13.24 & 14.08 & 12.47 \\
\hline & 3 & 95.59 & 37.18 & 9.76 & 9.55 & 10.59 & 7.48 \\
\hline \multirow{3}{*}{ Seed yield/plant (g) } & 1 & 93.35 & 48.91 & 18.46 & 17.83 & 10.95 & 18.60 \\
\hline & 2 & 95.55 & 17.53 & 16.19 & 15.82 & 4.84 & 5.85 \\
\hline & 3 & 96.06 & 32.12 & 11.37 & 11.15 & 8.86 & 7.52 \\
\hline \multirow{3}{*}{ 100-seed weight (g) } & 1 & 94.45 & 43.27 & 14.63 & 14.22 & 10.18 & 13.04 \\
\hline & 2 & 94.50 & 30.51 & 13.91 & 13.52 & 6.53 & 8.74 \\
\hline & 3 & 95.78 & 19.32 & 16.47 & 16.10 & 5.48 & 6.55 \\
\hline
\end{tabular}

\section{REFERENCES}

Abdallah, M.M.F. (1977). Performance of $F_{1}$ and $F_{2}$ hybrids of Vicia faba L. Egypt. J. Genet. Cytol. 6: 108-121.

Abdallah, M.M.F. and G. Fischbeck (1983). Hybrids between subspecies and types of Vicia faba L. grown under cages and in growth chambers. Ist .Conf.Agron. Egypt. Soc. of Crop Sci.51-71.

Abdelmula, A.A., W. Link, E. Kittlitz and D. Von Stelling (1999). Heterosis and iheritance of drought tolerance in faba bean (Vicia faba L). Plant Breed. 118, 485-490.

Al-Ghamdi, S.S. (2007). Genetic behavior of some selected faba bean genotypes. $8^{\text {th }}$ African Crop Science Society Conference, El-Minia, Egypt.

Attia, Sabah M., M.M. El-Hady, E.M. Rabie and Ola A.M. El-Galaly (2006). Genetical analysis of yield and its components using six populations model in faba bean [Vicia faba L.).

Bond, D.A., G.J. Jellis, G.G. Rowland, J. Le Guen, L.D. Robertson, S.A. Halil and L. 
Li Juan (1994). Present status and future strategy in breeding faba beans (Vicia faba L). for resistance to biotic and abiotic stresses. Euphytica 73: 151-166.

Burton, G.W. (1952). Quantitative inheritance in grasses. Proceedings of the $6^{\text {th }}$ International Grassland Congress, August 17-23, 1952, Pennsylvania State College, USA, pp. 277-283.

Cress, C.E. (1966). Heterosis of the hybrid related to gene frequency differences between two populations. Genetics. 53: 269-274.

EL-Galaly, Ola. A.M., R.A.I. Abo Mostafa and W.M. EL- Rodeny (2008). Evaluation of eight promising lines of faba bean (Vicia faba L.) for diseases resistance (chocolate spot and rust) and yield in North Delta . Annals of Agric Sc., Moshtohor, 46(2): 131-140.

El-Hady, M.M., Gh. A. Gad El-Karim and M.A. Omar (1997). Genetical studies in faba bean (Vicia faba L.). J. Agric. Sci. Mansoura Univ. 22: 3561-3571.

El-Hady, M.M., M.A. Omar, S.M. Naser, K.A. Ali and M.S. Essa (1998). Gene action on seed yield and of some yield components in $F_{1}$ and $F_{2}$ crosses among five faba bean (Vicia faba L.) genotypes. Bull. Fac. Agric., Cairo University, 49: 369-388.

El-Hady, M.M., Sabah M. Attia, A.A. Ashrei, E.A.A. El-Emam and M. Shaaban (2009). Heterosis, combining ability and genetic variability and some relative components in faba bean using six populations model. Minia J. Agric. Res. and Develop 29(3): 4187-431.

El-Hosary, A.A. (1981). Genetical studies on field bean (Vicia faba L.). Ph.D. Thesis Fac. of Agric. Menoufia University.

El-Hosary, A.A., S. Shokr, A.A.A. El-Halim, S.M. Nasr and A.M.A. Aziz (1997). Heterosis and combining ability in faba bean (Vicia faba L.). Egyptian J. of Agric. Res. 75 (3): 811-826.

El-Refaey, R. A. (1987). Studies on faba bean (Vacia faba L) breeding. Ph. D.
Thesis, Fac. Agric. Kafr El- Sheikh, Tanta University:119 pp.

El-Refaey, R.A. and M.M. Radi (1991). Genetic analysis of seed yield and its related character in soybean. IIInbreeding depression and interrelationships among traits in the $F_{1}$ and $F_{2}$ generations. J.Agric. Res.Tanta Univ., 17(2): 334-345.

El-Refaey, R.A., E.H. El-Seidy, A.A. ElGammal, M. Mansour and H.M. Ashry (2015). Estimation of heterosis and inbreeding depression in 4 barely crosses under normal and water stress condition. Agaric. Res.Kafer El-Sheikh Univ., 41(3): 885-901.

El-Refaey, R.A., A.A. El-Gammal, M.A. ElMoselhy and A.A. El-Naggar (2017). Quantitative inheritance of some barley agronomic traits under water stress condition. Menaufia J. Plant, Prod, 2, February: 39-51.

Gamble, E.E. (1962). Gene effects in corn (Zea mays L.). I- Separation and relative importance of gene effects for yield. Can. J. of Plant Sci., 42: 339-348.

Griffiths, D.W. and D.A. Laawes (1978). Variation in the crude protein content of field bean (Vicia faba L.). Inrelation to the possible improvement of the protein content of the crop. Euphytica, 27: 487495.

Hendawy, F.A. (1994). Heterosis and inheritance of some quantitative characters in two intervarietal crosses of field bean (Vicia faba L.) Minufiya J.Agric .Res.19:1957-1971

Jinkes, J.L. and R.M. Jones (1958). Estimation of the components of heterosis. Genetics, 43: 223-234.

Johnson, H.W., H.F. Robinson and R.E. Comstock (1955). Estimating of genetic and environmental variability in soybeans. Agron. J., 47: 314-318.

Lawes, D. S., D.A. Bond and M.H. Poulsen (1983). Classification, origin, breeding methods and objectives. : In: The Faba Bean (Vicia faba L.), P: 32-76.P.D. 
Hebblethwaite (ed.), Butterworths, London.

Kalia, P. and S. Sood (2004). Genetic variation and association analyses for pod yield and other agronomic and quality characters in an Indian Himalayan collection of broad bean (Vicia Faba L.). Sabrao Journal of breeding and genetics 36(2): 55-61.

Mather, K. (1949). Biometrical Genetics. Dover Publications, Inc., London

Mather, K. and J.L. Jinks (1971). Biometrical Genetics. second ed. Chapman and Hall Ltd., London, pp.382.

Miller, P.A., J. C. Williams, H. F. Robinson and R. E. Comstock (1958). Estimates of genotypic and environmental variances and covariance in upland cotton and their implications in selection. Agron. J., 50: 126-131.

Singh, B.B., U.P. Singh, R.M. Singh and B. Rai (1987). Genetic analysis of yield and yield components in field peas. J.Agric. Sci., Camb,109:67-71.

Smith, H.H. (1952). Fixing transgressive vigor in Nicotiana rustica. In heterosis, lowa State Collage Press. Ames, lowa, U. S. A.

Swarup, V. and D.S. Chaugale (1962). Studies on genetic variability in sorghum.1-Phenotypic variation and its heritable component in some important quantitative characters contributing towards yield. Ind.J. Genet. 22: 31-36.

Toker, C. (2004). Estimates of broad-sense heritability for seed yield and yield criteria in faba bean (Vicia faba L.) Hereditas 140: 222-225.

Wigan, L.G. (1944). Balance and potence in natural populations. J. Genet. 46:150160.

Warner, J.N.(1952). A method for estimating heritability. Agron. J. 44:427-430. 


\section{التحليل الوراثى للمحصول ومكوناته لثلاثة هجن من الفول البلدى باستخدام نموذج

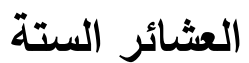

\section{جيهان جلال عبد الغفار أبوزيد}

مركز البحوث الزراعية ـ معهد بحوث المحاصيل الحقلية ـ قسم بحوث المحاصيل البقولية.

الملخص العربى أمبى

أجريت هذه الدراسه لتقدير بعض الدكونات الوراثيه للمحصول ومكوناته وكذلك حساب قوة الهجين ,التدهور الراجع الى التربية

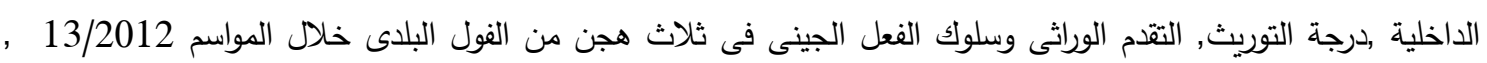

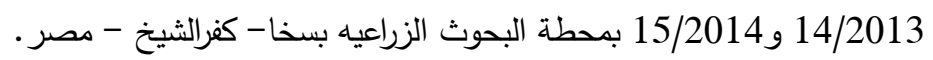
تم استخدام هقاييس العشائر الستة و هى الأب الأول, الأب الثاني , الجيل الأول ,الجيل الثاني, الهجين الرجعى الأول ,

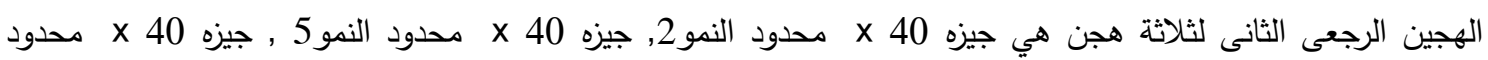

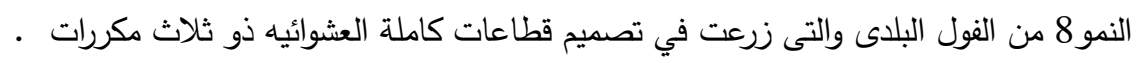

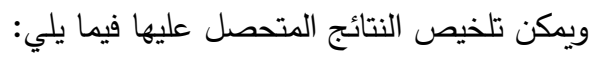
كان اختبار الميزان يختلف معنويا عن الصفر لجميع الصفات في كل الهجن الثلاثة بما يشير الى تواجد جميع الطرز والتفاعلات الغير أليليه. كانت تأثيرات الجينات السائده عالية من حيث القيمة لمعظم الصفات تحت الدراسه.

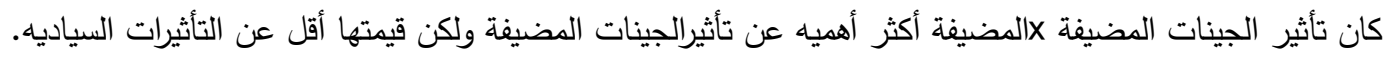

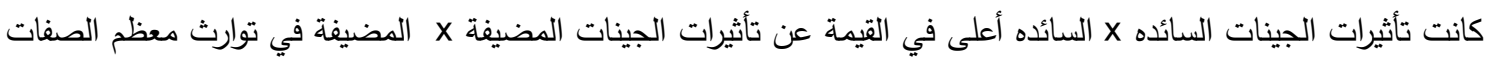

$$
\text { تحت الدراسه لجميع الهجن. }
$$
أظهرت قوة الهجين بناء على متوسط الأباء في الاتجاه المرغوب معنويه لصفة المحصول ومكوناته في الثلاث هجن و كانت

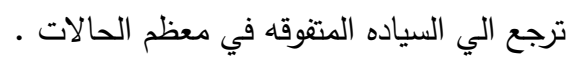

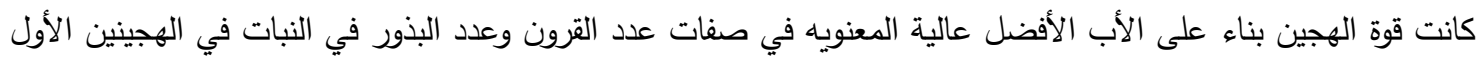
والثانى ولصفة محصول البذور للنبات ووزن 100-بذرة في الهجينين الثاني والثالث .

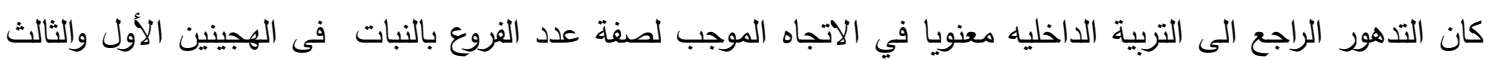
ولصفة عدد البذور بالنبات في الهجين الأول ولصفة عدد القرون بالنبات ومحصول البذور في الهجنين الأول والثاني .

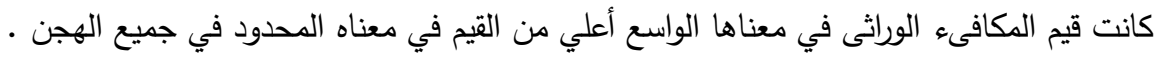

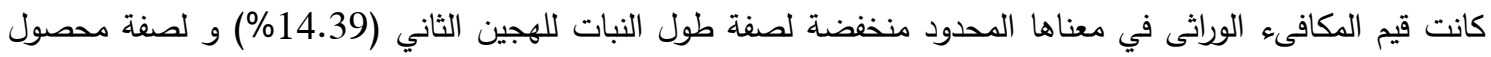
البذور في النبات في نفس الهجين ( 17.53\%) بما يشير أن هذه الصفات كانت متأثرة بالظروف البيئيه والفعل الجينى

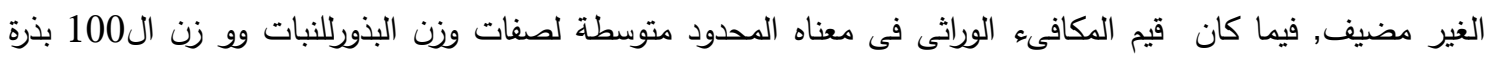

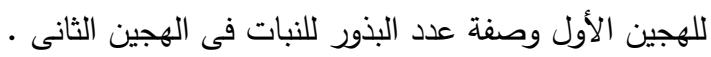
كانت القيم العالية للتقدم الوراثى المتتبأ به مرتبطة بالقيم العالية للمكافىء الوراثي • لإثي بمعناه المحدود والعكس بالعكس. 
